\title{
The Mobile Phone in India and Nepal: Political Economy, Politics and Society
}

\author{
Robin Jeffrey and Assa Doron
}

\begin{abstract}
This article scans the effects of mobile-phone communication, particularly in South Asia. It focuses on three important areas: political economy, politics and social practices. By 2012 India had more than 900 million telephone subscribers, 96 percent of them on cell phones, and the majority of users were the poor. At the other end of the social scale, the mobile phone provoked bitter struggles among some of India's biggest business houses and branches of government, and was responsible for criminal cases against politicians at the highest level.

The essays in this volume are a reminder that technology is anything but neutral. The essays examine the many facets of mobile phone communication and the institutions, agents, mechanisms and networks such communication relies on. The essays contribute to efforts to interpret the effects of this technology and to gain insight into the most important aspect of the mobile phone: the sheer variety of activity (political, social and cultural) on which it impinges.
\end{abstract}

KEYWORDS: cell phone, social networks; consumption; political economy

DOI: http:/ /dx.doi.org/10.5509/2012853469

$\mathrm{T}$

This collection invites readers to consider the consequences of the use of mobile phones by masses of people in India and Nepal. ${ }^{1}$ Since its arrival in India in 1994, the mobile phone has provoked bitter struggles among some of India's biggest business houses and branches of government, enabled the immense enrichment of a few start-up telecom companies and been responsible for criminal cases against politicians at the highest level. Meanwhile, near the bottom of the socio-economic pyramid, India by 2012 had more than 900 million telephone subscribers, 96 percent of them on

* Acknowledgements: The essays in this collection grew out of a workshop in Singapore on 17 and 18 February 2011 sponsored by the Institute of South Asian Studies (ISAS) at the National University of Singapore (NUS) and by the Australian National University (ANU) and its College of Asia and the Pacific, and the Australian Research Council (ARC). The editors and contributors express their thanks to ISAS, NUS, ANU and the ARC.

We use "mobile" and "cell phone" interchangeably, which is the way they are commonly used in India. 
mobile phones. ${ }^{2}$ From about 2005, when the cost of a mobile phone call fell to less than one rupee a minute (two US cents), poor people could afford to own and operate a cell phone. How did this come about and what does it mean for the way governments function and people live? The essays in this collection contribute to our understanding of these complex questions.

The mobile phone began to take off in India about the same time that studies of the mobile phone took off in the rest of the world. India in 2001 had 36 million phones, close to 75 percent of them landlines; by 2007, it had 206 million, 75 percent of them mobiles. ${ }^{3}$ Two books published in 2002 proved landmarks in attempts to understand the significance of the cell phone: Howard Rheingold's Smart Mobs: the Next Social Revolution and Perpetual Contact: Mobile Communication, Private Talk, Public Performance, a collection of 19 essays edited by James Katz and Mark Aakhus, most drawing on European experience. ${ }^{4}$ Katz and Aakhus puzzled at the lack of scholarly focus, up till that time, on the implications of the mobile phone. "It appears," they wrote, "that experts have difficulty discovering and interpreting even the communication taking place right in their own ears." ${ }^{5}$ Rheingold wrote a popular book based on his own remarkable knowledge of technology and of key people researching the field. Neither he nor Katz and Aakhus were "cyber-utopians," as critics sometimes refer to those who uncritically celebrate the capacity of mobile technology to liberate and democratize. ${ }^{6}$ But both books marvelled at the overthrow in 2001 of Philippines President Estrada through huge street demonstrations coordinated through mobile phones. ${ }^{7}$ The use of mobile phones had obvious consequences at the most public and political levels of society as well as in the most mundane practices of daily life.

The challenge for scholars trying to understand, interpret and speculate about the effects of the mobile phone lies in corralling a topic that runs away in a dozen directions. ${ }^{8}$ To impose order on such a slippery field, we can, for

\footnotetext{
2 Information Note to the Press (Press Release No. 38/2011), Telecom Regulatory Authority of India [hereafter TRAI], New Delhi, 13 June 2011, with figures to 30 April 2011, http://www.trai. gov.in/Default.asp, last accessed 5 April 2012.

3 TRAI figures for relevant years can be found at http://www.trai.gov.in/Default.asp, last accessed 5 April 2012.

$4 \quad$ Howard Rheingold, Smart Mobs: the Next Social Revolution (New York: Basic Books, 2002); James E. Katz and Mark A. Aakhus, eds., Perpetual Contact: Mobile Communication, Private Talk, Public Performance (New York: Cambridge University Press, 2002).

Katz and Aakhus, Perpetual Contact, 10.

Rheingold, Smart Mobs, xviii.

Rheingold, 157-8. Rheingold paid tribute to Vicente L. Rafael, "The Cell Phone and the Crowd: Messianic Politics in the Contemporary Philippines," Public Culture 15, no. 3 (Fall 2003): 399425. Rafael's academic article appeared a year after Rheingold's book. Katz and Aakhus, Perpetual Contact, 2-3.

8 Leslie Haddon, Information and Communication Technologies in Everyday Life: a Concise Introduction and Research Guide (Oxford: Berg, 2004), 2-3, identified this diversity of possible approaches in an early survey of the field.
} 
purposes of this collection, fence off research into three categories, each likely, however, to invade the other's territory once exploration begins:

- political economy;

- politics; and

- social practices.

Essays in the current collection contribute to our understanding of one or other of these corrals of convenience. Though the collection is weighted towards political economy and social practices with only a single essay on the purely political, the political implications of mobile phones pose one of the key puzzles and we therefore explore them in a little more detail in this introduction.

\section{Political economy}

In published research about the mobile phone, the political economy of the device has up till now received perhaps least consideration. There is plenty of journalism about cell phone companies, but few attempts to understand the broader patterns of their behaviour or its implications. Jon Agar's trailblazing book Constant Touch: a Global History of the Mobile Phone in 2003 provided a quick gallop across the patterns of interests that competed to introduce mobile technology to Europe and North America from the 1980s. ${ }^{9}$ But the competition of great corporations and governments to control and exploit an invisible resource-Radio Frequency spectrum-is difficult to comprehend in all its complexity and even more difficult to explain concisely. What is perhaps most significant is that digital telecom industries, which developed from the 1980s in the US and Europe, create an ants' nest of interconnected activity. This industrial complex is as vast as the automobile industry that emerged from the 1920s. In the current collection, the essays by Mani and Gupta cast light on how this way-of-life-changing industry has developed in India.

From the development of commercial radio after the First World War, it was clear that control of Radio Frequency spectrum could bring great profit. The development in the 1980s of small receiver-transmitters-the mobile phone-brought tantalizing prospects. The reconfiguring of national telecommunications systems in the 1980s varied from country to country, but the trend was to reduce or eliminate the role of government and open the provision of telephones and telecom services to private enterprise. By the mid-1980s, this process had begun even in India, where telephones were rare and the government-run service abysmal. By the time of India's financial

\footnotetext{
9 Jon Agar, Constant Touch: a Global History of the Mobile Phone (Cambridge: Icon Books, 2003), especially chapter $8,70-89$.
} 
crisis in 1991, the Rajiv Gandhi government (1984-89) had begun to loosen the government grip and to improve public access to landlines. Indian business organizations clamoured for an end to the government monopoly over telecom, and the Indian coalition government of 1989-90 commissioned a report to recommend how telecommunications should be deregulated. ${ }^{10}$ The financial crisis of 1991 and the election of the Congress government under P.V. Narasimha Rao after Rajiv Gandhi's assassination provided the final push that brought private interests into the field of telecommunications.

Because of the high stakes of profit and patronage, some of the biggest players in Indian capitalism and politics were involved. Bureaucrats and their political allies in the Department of Telecommunications struggled to retain control and thwart the efforts of rivals in the Congress government to deregulate the industry. Ashok Desai captured the comic-opera folly of an elected government often being frustrated by one of its own departments. ${ }^{11}$ India, however, has not been alone in such contortions, as Agar and others have shown. ${ }^{12}$

In this collection, Gupta focuses on the crucial question of competition. Did abandonment of the government monopoly and the introduction of capitalist competition lead to the vast expansion of phones? Yes, is his answer; but the process was tortuous. As a magnet for Indian capital, the partially deregulated telecom industry provided an arena where big capital and vested bureaucratic and political interests wrestled for control. By 2002, after an agonizing ten years of false starts, poor judgement, hamstringing regulation and blatant corruption, a fairly open playing field was defined and competition among about a dozen providers drove the explosive expansion of mobile phone connections..$^{13}$ The short-term future, Gupta concluded in 2012, looked healthy for both consumers and providers, but there were indications that the industry would eventually shrink to an oligopoly of two or three great companies. Supreme Court judgements in February 2012 that overturned improper allocation of spectrum four years earlier reinforced the sense that the Indian telecom industry was ripe for a contraction in the number of providers. ${ }^{14}$

"What is not in doubt," asserts one of the pioneers of research on mobile phones, "is that the telephone itself fosters employment growth, not the least to serve itself as an industry." ${ }^{15}$ Mani explores the extent to which the spread

10 M.B. Athreya, "India's Telecommunications Policy: a Paradigm Shift," Telecommunications Policy 20, no. 1 (1996): 11-22. See also Ashok V. Desai, India’s Telecommunications Industry (New Delhi: Sage, 2006).

11 Desai, India's Telecommunications Industry, 75-84.

12 Agar, Constant Touch, 31-43.

13 For details see Robin Jeffrey and Assa Doron, The Great Indian Phone Book: How the Cheap Mobile Changes Business, Politics and People's Lives (forthcoming, 2012).

14 Hindu, 5 April 2012, http://www.thehindu.com/news/national/article3281130. ece?homepage=true, last accessed 5 April 2012.

15 James E. Katz, Magic in the Air (New Brunswick, NJ: Transaction Publishers, 2006), 121. See also James E. Katz, ed., Handbook of Mobile Communication Studies (Cambridge, MA: MIT Press, 2008). 
of mobile phones in India has led to the creation of a new manufacturing industry. He concludes that to a limited extent this has happened. By 2009, India had become a net exporter of mobile handsets. But most of the tiny components of these handsets were made in China. Though India's factories were doing complex assembly, they were not manufacturing from scratch. The role of China and Chinese exports on Indian telecommunications remained substantial, as Amitendu Palit's essay, "Dragon in the Elephant's Backyard: Chinese Imports in India's Mobile Revolution," illustrates.

\section{Politics}

When analyzing the changes in human practices that take shape around the mobile phone, a distinction between politics and political economy is useful. "Political economy" focuses on the contests among those organizations that assemble the vast amounts of capital necessary to establish mobile phone networks, and aim to benefit from the expected profits. "Politics" concerns the use to which people can turn the device to acquire, retain or enhance power. There are opposite schools of interpretation about what the mobile phone and its offshoots achieve. At the idealistic end of the spectrum, "cyber optimists," as they are sometimes called, see the power of individuals to communicate and broadcast as almost unalloyed liberation. Clay Shirky, author of Here Comes Everybody: How Change Happens When People Come Together, writes that what Google is “exporting isn't a product or a service, it's a freedom [sic]." 16

At the other extreme, critics see the technology as opening insidious new possibilities for governments to monitor, indoctrinate and control their citizens. Questions of security and surveillance arise constantly in studies of the mobile phone. Morotzov's Internet Delusion, a debunking of "cyber utopianism," argues that "tremendous cost savings introduced by digital surveillance technologies have ... made it possible to shift surveillance personnel to more burning tasks." ${ }^{17}$ There is no doubt that a mobile phone can put the user in danger if the user is unwary and others want to know badly enough what particular people are doing or saying. But users are not inert. In Nepal in 2005, though the shutdown of the mobile phone network succeeded in checkmating anti-government protests for a time, the dislocation and dismay that the shutdown generated proved a landmark. Opinion among outraged citizens, habituated to using mobiles to conduct daily tasks in a country of difficult terrain, turned emphatically against the king's government. Within a year, the king had lost most of his powers, and

16 Clay Shirky, Here Comes Everybody: How Change Happens When People Come Together (London: Penguin, 2009). The quotation comes from http://server-nexa.polito.it/pipermail/nexa/2010March/000815.html, last accessed 7 July 2011.

Evgeny Morozov, The Net Delusion: How Not to Liberate the World (London: Allen Lane, 2011), 152. 
by 2008 the monarchy was abolished. The mobile phone did not make this happen, but it had become as necessary a commodity for large numbers of people as salt in the diet. What annoys large numbers will trouble, and even challenge, rulers.

Ang's essay on the Nepal example is particularly valuable because it details the way in which people respond when something they value is suddenly withdrawn. The essay suggests that the benefits that power-holders gain from curtailing a technology are limited, particularly when their own support depends on the same technology. This is not to say that more subtle methods for tracking the users of mobile phones cannot be found; but in such games of cat and mouse, the mice have new capabilities. To be sure, the capacity of "the people" to mobilize to overthrow an Estrada in the Philippines in 2001 needs to be balanced against the capacity of "the authorities" to trace and punish mobile-phone users in Iran in 2009. But in less violent circumstances (an Indian election, for example), the cheap mobile phone provides poor people with a means of communicating and coordinating that they have never had before, as the 2007 elections in India's Uttar Pradesh state demonstrated. A political party with a low-caste base but a committed cadre of workers was able to use this commitment and organization as never before-because each worker had a mobile phone and was in regular touch with party strategists and organizers..$^{18}$

Rafael's seminal article, which Rheingold took up in Smart Mobs and Katz and Aarhus in Perpetual Contact, explained how mobiles had been used to get crowds into the streets of Manila during the demonstrations that brought down President Estrada of the Philippines in 2000-01. A number of studies have focused on the mobile as a device allowing citizens to join together to challenge governments. However, a mere catalyzing moment when crowds gather is insufficient to effect long-term change. The potency of the mobile phone, however, lies in its affordable autonomy and its consequent ability to multiply by many times the efficient reach of existing, highly motivated organizations. In such circumstances, the mobile can give low-status, less powerful groups a weapon that they previously lacked: low-cost, hard-to-stop communications.

The technology, however, is not neutral. A mobile phone needs a network of transmission towers and service providers if it is to be more than a lump of plastic and metal. It also needs batteries and electricity to charge them. A well-understood class system quickly develops around mobile devices: some devices are far more suave, sophisticated and expensive than others. The mobile phone does not diminish the advantages of the wealthy-the people, for example, whose companies "own" Radio Frequency spectrum-but it puts a remarkable and sometimes an equalizing device in the hands of the poor.

18 Robin Jeffrey and Assa Doron, "Mobile-izing: democracy, organization and India's first 'mass mobile phone' elections,” Journal of Asian Studies 71, no. 1 (February 2012): 63-80. 

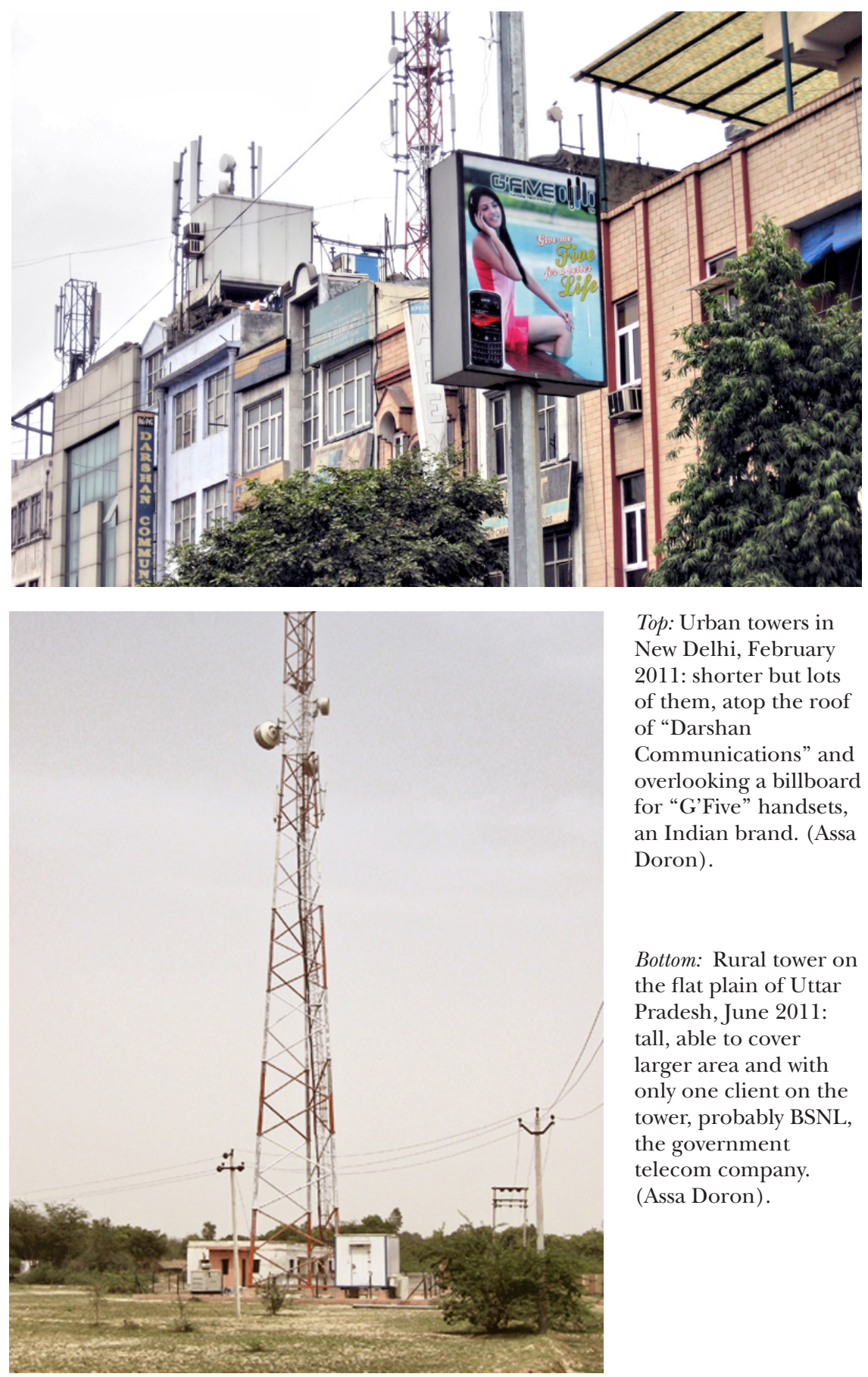

Top: Urban towers in New Delhi, February 2011: shorter but lots of them, atop the roof of "Darshan

Communications" and overlooking a billboard for "G'Five" handsets, an Indian brand. (Assa Doron).

Bottom: Rural tower on the flat plain of Uttar Pradesh, June 2011: tall, able to cover larger area and with only one client on the tower, probably BSNL, the government telecom company. (Assa Doron). 


\section{Social Practices}

One can envisage the mobile phone as a crucial part of a grand theory of social practice and communication. Manuel Castells argued in the 1990s that humanity was experiencing The Rise of the Network Society in which "digital networking technologies ... powered social and organizational networks in ways that allowed their endless expansion and reconfiguration." ${ }^{19}$ The "material basis" now existed for the "pervasive expansion throughout the entire social structure" of the "networking form of social organization." ${ }^{20}$ The cheap mass mobile phone provides that "material basis" - the device—by which vast numbers of people acquire the capacity (and the need?) to be part of this "network society." Scholars have developed Castells' ideas. Jack Linchuan Qiu writes of Working-Class Network Society in which vast numbers of "the information have-less" in China nevertheless have acquired the potential "to build civic bonds among members of the new working class." Robin Singh Grewal conceptualizes Network Power as the way in which tens of millions of individual choices, aggregated by digital technologies, create "a relatively coercive social structure" yet one that is "compatible with ... a robust view of individual agency." 22 Like Castells and Qiu, Grewal sees digital technology as giving wide, new choice to tens of millions of people, though such choice brings with it pressures that strongly favour particular responses. Because of its cheapness, simplicity and ubiquity, the mobile phone is a device that weaves hundreds of millions of threads into the fabric of network society.

In this collection, Doron's study of the repair economy for mobile phones shows how even relatively poor individuals are called on to exercise such choices. When a mobile phone won't work, how does one get it repaired? Users can go to their local market and find one of the cottage-industry repair stalls, operating rather like the roadside repairers of punctured bicycle tyres, for a quick, unguaranteed fix. Such petty businesses respond to the need for distinctively local participation in the global economy. These businesses draw on existing skills, cultural traditions and social capital and enable many of India's consumers to evade the full impact of brand-built global capitalism. The latter glamorizes objects and builds in rapid obsolescence, either through the dictates of fashion or the need to "upgrade." Alongside this informal repair economy, however, a brand-led alternative spreads rapidly. Users can take their faulty phones to a Samsung, Nokia or other big-brand customerservice centre, pull a ticket from the machine, sit in a plastic chair and wait

\footnotetext{
19 Manuel Castells, The Rise of the Network Society, 2nd edition (Chichester: Wiley-Blackwell, 2010; first published 1996), xviii.

${ }_{20}$ Castells, 500.

21 Jack Lichuan Qiu, Working-Class Network Society: Communication Technology and the Information Have-Less in Urban China (Cambridge, MA: MIT Press, 2009), 248.

${ }^{22}$ Robin Singh Grewal, Network Power: The Social Dynamics of Globalization (New Haven: Yale University Press, 2008), 56.
} 


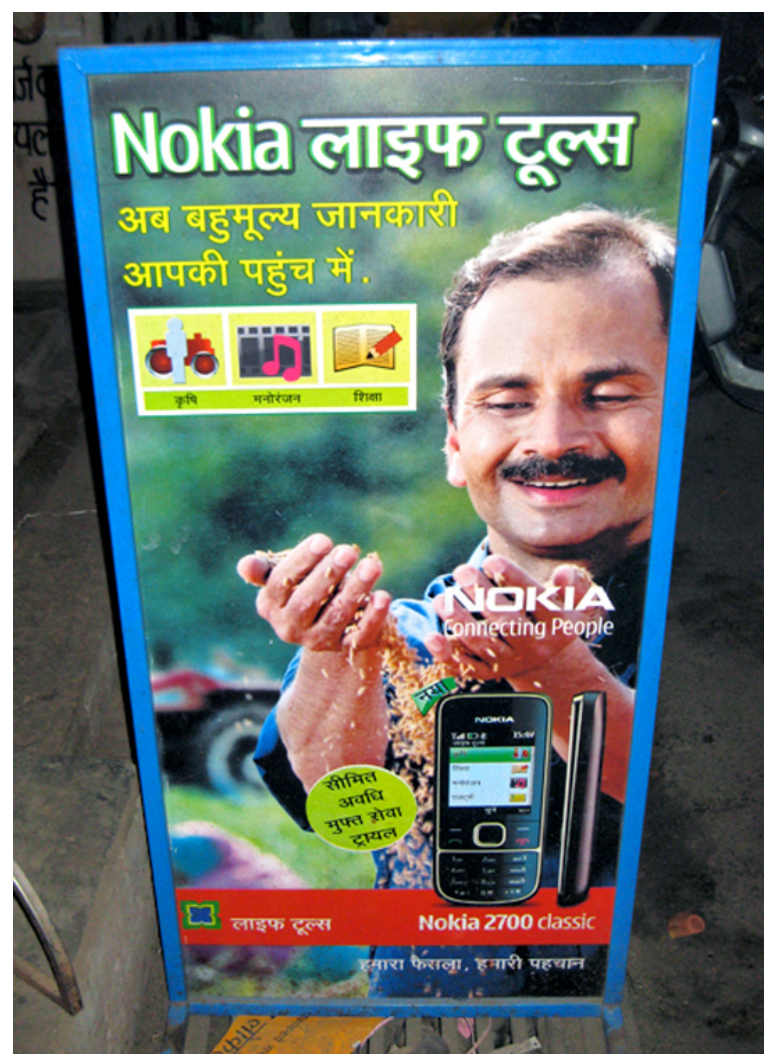

Nokia outdoor advertising, January 2010: "Nokia laaiif tuuls [life tools]. Valuable information - within your reach." (Assa Doron).

to be called by a young woman wearing a corporate tee-shirt. Owning the device leads a person to purpose-built showrooms where people are socialized into the rituals of global consumerism. Owning a mobile phone forces millions of people to "choose" to interact continually with great corporations and the state. Perhaps for the first time, they become threads in the fabric of global networks.

Rangaswamy and Cutrell in this collection provide a striking example of how networks are born, connect and take their place as part of a global tapestry. In the case of GupShup (gossip), all this happens through the simplest and cheapest device: the $2 \mathrm{G}$ mobile phone. ${ }^{23}$ In 2010 , there were 40 million GupShup subscribers and 3 million GupShup lists. Each list was controlled by a single person; anyone could start a list; and some lists had up to 300,000 members. The "owner" of a GupShup list transmitted messages to subscribers, but the subscribers were not in touch with each other. List owners valued the self-importance of being at the centre of such a web and

23 See http://www.smsgupshup.com/about, last accessed 4 April 2012. 
used the reach of their lists to advertise people and products. The owner of a list sent a stream of SMSs (maximum 140 characters) every day, passing on jokes, explaining ways of using mobile phones and computers and transmitting advertisements and snippets of news. GupShup allowed individuals to broadcast and perform-to become small-scale impresarios, sometimes with very large audiences.

The study of GupShup suggests other ways of viewing the digital revolution and its most pervasive carrier, the cheap cell phone. Since the late 1990s, anthropologists have often asked two broad questions about the effects of the mobile phone: "How do people use this new tool? Does it change patterns of behaviour or simply reinforce existing practices?" To try to get a grip on the vast variety of global experiences, pioneering work by Horst, Miller, Katz and Ling sometimes worked with concepts labelled "domestication" and "performativity." 24

"Domestication" involves the ways in which new devices-in this case, the mobile phone-are made part of daily life: how people adapt them to their own needs and circumstances. GupShup is a fine example: its lists provide cheap, easy entertainment, information and a sense of self-importance. Many of the essays in the path-breaking Perpetual Contact dealt with similar themes as they related to the arrival of the mobile phone in Europe and Japan in the 1990s. How and why did people take the mobile phone into their daily lives? ${ }^{25}$ Pure sociability appears to be one reason: the human desire to interact with others. Daniel Miller describes how people on the island of Trinidad in the West Indies use Facebook similarly to the way Indians use GupShup: they exchange " news and commentary ..., sayings and ruminations ..., jokes and various kinds of humour." Such exchanges, Miller suggests, "help us return to the kind of involvement in social networks that we believe we have lost." 26 It is worth recalling that the businessmen who propagated the first telephones in North America took some time to discover that the desire for social conversation sold phones more widely and quickly than a wish to do business or to call for help. ${ }^{27}$

Another category of research about the social aspects of the mobile phone focuses on "performativity": the way a device becomes a prop that individuals use in presenting themselves to the world. Everyone has a sense of how the world sees them, and everyone thinks, at least occasionally, about how they are presenting themselves to their world. Unlike a striking haircut, a flashy

24 Heather Horst and Daniel Miller, The Cell Phone: an Anthropology of Communication (Oxford: Berg, 2006); Rich Ling, The Mobile Connection: the Cell Phone's Impact on Society (San Francisco: Elsevier, 2004); James E. Katz, ed., Handbook of Mobile Communication Studies (Cambridge, MA: MIT Press, 2008).

${ }_{25}$ Mizuko Ito, Daisuke Okabe and Misa Matsuda, eds., Personal, Portable, Pedestrian: Mobile Phones in Japanese Life (Cambridge, MA: MIT Press, 2005). The 15 essays focus particularly on young people's use of mobiles in Japan.

26 Daniel Miller, Tales from Facebook (Cambridge: Polity, 2011), 212, 217.

27 Claude S. Fisher, America Calling: a Social History of the Telephone (Berkley: University of California Press, 1994), 85. 
watch or particular physical mannerisms, the mobile phone not only allows a person to make a fashion statement but enables a user to become a broadcast personality and have an audience of thousands. As Manuel Castells writes, "mobile communication is not about mobility but about autonomy"the ability of individuals to $b e$ individual and to do things they have never done before. ${ }^{28}$

Proponents of Actor Network Theory (ANT) have long focussed on the way in which networks are produced by the interaction between technical devices and social practices. They argue against an artificial division of objects, on the one hand, and people on the other. Rather, they suggest a two-way, or dialectical, understanding that sees "things" (e.g., mobile phones) as essential parts of human experience. New "things" or tools change the way we relate to institutions, objects, policies, events and the actions of others. ${ }^{29}$

"A network is never bigger than another one," writes Bruno Latour, ANT's most prominent exponent, "it is simply longer or more intensely connected." By this, Latour seems to mean that what is important in networks is the intensity and resilience-not the number-of their connections. A vast network in the digital age may quickly vanish: witness the Gigapedia website. ${ }^{30}$ What is important is the vigour of the ties. Such observations resonate particularly with Rangaswamy's and Cutrell's analysis of the expanding network of SMS GupShup, whose units grow, spread and dissolve like pieces of a coral reef. Size is significant, but the value of each of GupShup's constituent networks to its creator lies in the intensity of activity it generates. At first sight, a GupShup network may appear like an Indian version of social networking platforms such as Twitter. Yet, as the authors argue, SMS GupShup is unique; it caters for enterprising people seeking, not to socialize so much as to maximize commercial and economic opportunities. Friendship, to paraphrase Mae West, has nothing (or very little) to do with it. As Rangaswamy and Cutrell document, the creators (mostly young men) of vibrant GupShup lists are usually from small towns and humble circumstances. The creator of a GupShup list presides over a network that is, as Latour writes, "a highly connected one which remains nevertheless continuously local." ${ }^{11}$

Similarly, as Doron argues, the repairmen on the footpaths of Indian towns are inseparable from a wide, dense and complex network of social and technical relations. When one examines these connections more closely, their range and depth are astounding. The mobile phone that these repairmen routinely pry open connects India to Africa, China and North America. The

\footnotetext{
28 Manuel Castells, “Afterword," in James E. Katz, ed., Handbook of Mobile Communication Studies (Cambridge, MA: MIT Press, 2008), 448.

29 Bruno Latour, "On Actor Network Theory: a few clarifications plus more than a few complications," 1996, 4, see http://www9.georgetown.edu/faculty/irvinem/theory/Latour -clarifications.pdf, accessed 4 April 2012.

${ }_{30}$ Gigapedia was a website said to have held more than 400,000 books available for free download. Legal action by a consortium of international publishers closed the site in February 2012.

31 Bruno Latour, "On Actor Network Theory,” 4.
} 
phone links the small-town repairer to labourers and networks throughout the world that produce the phone and make it work. ${ }^{32}$ The search for rare earths, vital for the production of mobile phones, has thrown the Eastern Democratic Republic of Congo into disarray, and the extraction of such metals comes at a great human and environmental cost. ${ }^{33}$ At the same time, the world's dominant producer of rare earths, China, controls the market and restricts exports to the dismay of demanding consumers all over the globe. ${ }^{34}$

Such connections are not new. But their pervasiveness and intensity are. The experience is different from that of a specialized watch repairer in Calcutta in 1890 or an expert printer in Amsterdam in 1600. By highlighting these connections, we begin to understand the social and technical relationships embodied in objects like the mobile phone. Categories such as politics, political economy and social practices of course remain useful in describing and understanding that reality; but we need to probe such concepts to see how they connect to the vast, dense networks now contained in the digital world and its most basic tool, the apparently neutral "thing": the cheap cell phone.

The essays in the present collection contribute to a better understanding of the ways in which national and regional cultures fashion a device to suit their own needs. Heather Horst and Daniel Miller were among the pioneers of such studies with The Cell Phone: an Anthropology of Communication, a study of Jamaica, published in 2006. Within five years, there were monographs to cover the globe from Japan and China to Africa. ${ }^{35}$ The essays in this collection add complexity and depth to the Indian picture, where crucial early brushstrokes were provided by Jonathan Donner and his associates. ${ }^{36}$

Vast fields are yet to be explored. Socially, there is no discussion here of power struggles within households to control mobile phones, nor of the mobile's role in providing religious inspiration and connection, nor of the place of the mobile in removing the isolation of village life. (Peasants with

32 See the Latour example of the "hammer" in Bruno Latour, "Morality and Technology: The End of the Means," Theory, Culture and Society 19, nos. 5-6 (2002): 247-260.

33 On the conflicts surrounding the mining of rare earths used commonly in cell phones, see James. H. Smith, "Tantalus in the Digital Age: coltan ore, temporal dispossession, and 'movement' in the Eastern Democratic Republic of Congo," American Ethnologist 38, no. 1 (2011):17-35.

34 See http://topics.nytimes.com/top/reference/timestopics/subjects/r/rare_earths/index. html, last accessed 6 April 2012.

$\frac{{ }_{35}}{3}$ Mizuko Ito, Daisuke Okabe and Misa Matsuda, eds., Personal, Portable, Pedestrian: Mobile Phones in Japanese Life (Cambridge, MA: MIT Press, 2005); Jack Linchuan Qiu, Working-Class Network Society: Communication Technology and the Information Have-Less in Urban China (Cambridge, MA: MIT Press, 2009); Mirjam de Bruijn, Francis Nyamnjoh and Inge Brinkman, eds., Mobile Phones: the New Talking Drums of Everyday Africa (Bamenda, Cameroon and Leiden, The Netherlands: Langa and African Studies Centre, 2009).

36 Rich Ling and Jonathan Donner, Mobile Communication (Cambridge: Polity, 2009), 168-9, for examples of Donner's wide-ranging contributions. 
mobiles are no longer potatoes in Marx's sack). This collection also does not touch on the cascade of occupations involved in making mobile phones, building and maintaining their networks, and getting people to buy them. How big is the "mobile phone industry"?

What readers will find here, however, are insights into the most important aspect of the mobile phone: the sheer variety of human activity on which it impinges. From governments and great capitalists to barrows in back streets, the individualized use of Radio Frequency confronts people with new opportunities, incentives and pressures to change the way they live.

National University of Singapore, Singapore

Australian National University, Canberra, Australia, May 2012 